\title{
Chemosensitization of leukemia cells through inhibition of NAMPT
}

\author{
Theresa Gorski ${ }^{*}$ Stefanie Petzold-Quinque, Susanne Schuster, Melanie Penke, Sandy Richter, Wieland Kiess, \\ Antje Garten
}

From Metabolism, Diet and Disease 2014: Cancer and metabolism

Washington DC, USA. 28-30 May 2014

\section{Background}

NAMPT (Nicotinamide phosphoribosyltransferase) catalyzes the rate-limiting step in the NAD-biosynthesis from nicotinamide and regulates the activity of NADdependent enzymes. Cancer cells are highly dependent on NAD for energy and DNA repair processes and are expected to be more susceptible to the inhibition of NAD synthesis than non-transformed cells. Can inhibition of NAMPT by FK866 sensitize leukemia cells for chemotherapeutic agents?

\section{Materials and methods}

Viability was measured using WST-1 assay. Cell death was analysed in Jurkat and Molt-4 cells by PI staining. NAD levels were measured using a colorimetric NAD/NADH Assay or HPLC. NAMPT activity was measured in leukemia cell lines and PBMCs (peripheral blood mononuclear cell) using radioactively labelled ${ }^{14} \mathrm{C}$-nicotinamide.

\section{Results}

NAMPT expression and enzymatic activity were significantly higher in leukemia cell lines compared to normal PBMCs. Incubation with FK866 [10nM] for 24h reduced NAMPT activity by $91.1 \pm 3.6 \%$ in Jurkat cells and by 97.8 $\pm 1.2 \%$ in Molt -4 cells. NAD levels were reduced by FK866 by $83.9 \pm 1.0 \%$ (Jurkat) or $79.2 \pm 2.8 \%$ (Molt- 4 ). The combination of etoposide and FK866 caused increased cell death compared to each substance alone. In contrast, combining FK866 and methotrexate or doxorubicin showed no increased effect on cell death. Etoposide decreased the expression of the NAD-dependent deacetylase SIRTUIN1 (SIRT1). The acetylation of the SIRT1 target p53 was increased after stimulation with etoposide

\footnotetext{
Center for Pediatric Research Leipzig (CPL), University Hospital for Children and Adolescents, University of Leipzig, Leipzig, Germany
}

and was further enhanced after combining etoposide with FK866. Concomitantly, the transcriptional activity of p53 was increased as shown by an increased expression of $\mathrm{p} 21$.

\section{Conclusion}

The combination of etoposide and FK866 caused increased cell death and induced acetylation and transcriptional activity of p53. Combining FK866 and etoposide could therefore be a novel therapeutic strategy to enhance the efficacy of etoposide against leukemia cells.

Published: 28 May 2014

doi:10.1186/2049-3002-2-S1-P24

Cite this article as: Gorski et al.: Chemosensitization of leukemia cells through inhibition of NAMPT. Cancer \& Metabolism 2014 2(Suppl 1):P24.

\footnotetext{
Submit your next manuscript to BioMed Central and take full advantage of:

- Convenient online submission

- Thorough peer review

- No space constraints or color figure charges

- Immediate publication on acceptance

- Inclusion in PubMed, CAS, Scopus and Google Scholar

- Research which is freely available for redistribution

Submit your manuscript at www.biomedcentral.com/submit
}

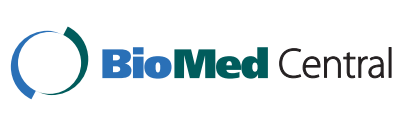

(c) 2014 Gorski et al; licensee BioMed Central Ltd. This is an Open Access article distributed under the terms of the Creative Commons Attribution License (http://creativecommons.org/licenses/by/4.0), which permits unrestricted use, distribution, and reproduction in any medium, provided the original work is properly cited. The Creative Commons Public Domain Dedication waiver (http:// creativecommons.org/publicdomain/zero/1.0/) applies to the data made available in this article, unless otherwise stated. 